\title{
An Analysis of the Female Ideologies in Bunner Sisters from the Perspective of "Power-Over"
}

\author{
Yuemeng $\mathrm{Xu}^{1}$, Yongjie $\mathrm{Liu}^{2 *}$ \\ ${ }^{1}$ Institute of Modern History, Chinese Academy of Social Sciences, 1 Dongchanghutong, Dongcheng District, Beijing, 100006, China \\ ${ }^{2}$ Research Institute for Global Value Chains, University of International Business and Economics, 10 Huixindongjie, Chaoyang District, \\ Beijing, 100029, China
}

Corresponding Author: Yongjie Liu, E-mail: liuyongjie@uibe.edu.cn

\author{
ARTICLE INFO \\ Article history \\ Received: July 01, 2018 \\ Accepted: September 03, 2018 \\ Published: December 01, 2018 \\ Volume: 7 Issue: 7 \\ Advance access: October 2018 \\ Special Issue on Language \& \\ Literature
}

Conflicts of interest: None

Funding: None

\begin{abstract}
The idea of patriarchy makes the subordination and oppression of women by men visible and illegitimate. Starhawk labels the dominant and oppressive type of power that reinforces obedience in patriarchy power-over, an exploitative form of power that celebrates and encourages manipulation and a view of the world as mechanistic and disconnected. From the perspective of what Starhawk defines as "power-over", this paper examines the female ideologies of the Bunner sisters - the passive victims of the patriarchal system - constructed under the influence of the patriarchal system in terms of such key elements as misplaced conception of culture and literacy, the "virtue" of self-abnegation and absolute obedience to and dependence on the authority which are deeply entrenched in the character of the two sisters.
\end{abstract}

Key words: Female Ideologies, Patriarchy, Edith Wharton, Bunner Sisters

\section{INTRODUCTION}

Bunner Sisters depicts two spinster sisters, Ann Eliza and Evelina Bunner, who run a sewing shop off Stuyvesant Square and sell needles and thread. The Bunner sisters manage well enough until Herman Ramy, a German immigrant of dubious intentions, enters their lives, displays an interest in Ann Eliza, the older and more self-sacrificing one, and then marries the younger, shallower Evelina and takes her away. Feeling utterly bereft, the anguished elder sister faces a bleak future, but considerable problems and appalling tragedy may lie ahead: Ramy is discovered to be a drug addict; hence Evelina suffers agonies of penury and brutality, including the death of her child, and then finally returns to the shop mortally ill and in despair. When Evelina dies, Ann Eliza is left with no alternative but to sell what little remains in the shop and wander the streets, looking for some means of survival.

Ann Eliza and Evelina Bunner are portrayed by Wharton as the passive victims of the patriarchal system. Patriarchy, a key concept used by feminists in recent years, means that men dominate women and children in families as in every aspect of wider social and political systems. It encapsulates the mechanisms, ideology and social structures which have enabled men throughout much of human history to gain and to maintain their domination over women. The idea of patriarchy enables women to see their personal experiences as part of a general sexual politics in which they share interests with other women. It makes the subordination and oppression of women by men visible and illegitimate.

An ideology, a way of looking at things, is a set of conscious and unconscious ideas that constitute one's goals, expectations and actions. The Bunner sisters adopt the dominant ideologies of patriarchal society, which they are unable to resist because of its subtle techniques of inducement. Although dominant ideologies once relied for their compulsion on explicit, overt forms of enforcement, they gradually become more indirect and subtle, relying on prevailing social codes. Misplaced conceptions of culture and literacy, the "virtue" of self-abnegation as well as the absolute obedience to and dependence on the authority are deeply entrenched in the character of the two sisters. This paper examines the female ideologies - that of the Bunner sisters in particular - constructed under the influence of the patriarchal system from the perspective of what Starhawk defines as "power-over".

\section{PATRIARCHY AND "POWER-OVER"}

Patriarchy is a sexist social system that is distinctly unnatural and constitutes a limiting and destructive realm for women. This realm is a "male-centered and monodimensional arena" where fabrication, objectification and alienation take place and where women's identities, self-images and experiences are so distorted that they rarely reflect the truths of women's lives. 
Patriarchy, according to Starhawk, is a hierarchical system maintained by "the belief that some people are more valuable than others" (84). In a hierarchical system such as patriarchy, those on the top command, and those below obey. Although in some hierarchies, Starhawk recognizes, those with more power empower those with less, this rarely happens in a patriarchal system. Patriarchy perpetuates the dominance of some individuals over others, and is designed to make that dominance seem normal or natural. The dominance of the masculine side of each dichotomy and the corresponding devaluation of the female is a powerful characteristic of patriarchy. Patriarchy promotes insecurity and self-denial and "teaches us that our worth is not a given but must be earned and subordinated to the value of someone else whose status is higher than ours" (Starhawk 66).

Hierarchy in the patriarchal world requires obedience, which Starhawk describes as "the destruction of the self". To be obedient is to be a slave without freedom: "When we comply, when we aid the system in its ultimate disregard and destruction of us, we hate ourselves" (Starhawk 81). In patriarchy, obedience becomes possible because it is "etched in the psyche, too deep to be questioned, and reinforced by training, religion, and ideology" (Starhawk 53).

Starhawk labels the dominant and oppressive type of power that reinforces obedience in patriarchy power-over. "Power-over" is an exploitative form of power that celebrates and encourages manipulation and a view of the world as mechanistic and disconnected; ultimately, it divides, manipulates, and controls individuals. In the structure of "power-over", "good people obey the rules", and authority, which is dependent on one's position in the patriarchal hierarchy, is placed "in a realm beyond question, valued above reason or the evidence of the senses" (Starhawk 34). "Power-over" allows individuals "to cause pain and suffering quite comfortably in defense of the rules" (Starhawk 34). It tears down rather than builds up and is "the story of the literal dismemberment of the world, the tearing apart of the fabric of living interrelationships that once governed human life" (Starhawk 32).

\section{MISPLACED CONCEPTIONS OF CULTURE AND LITERACY AS REFLECTION OF PATRIARCHAL INFLUENCE}

Bunner Sisters can be read as a survey of the literary field and a meditation on literary culture, especially the implications of reading such publications as novels, poems and newspapers (Hochman 128). The seductive appeal of "culture" for the Bunner sisters is significant in the novella. The fatal attraction of Mr. Ramy in the eyes of Ann Eliza and Evelina Bunner is much enhanced by their perception of him as an "educated man" (Wharton 19, 30), one whose "culture [soars] beyond the newspapers" (Wharton 49).

However, an unthinking embrace of "the literacy myth" can be dangerous (Hochman 137). Bunner Sisters stresses the damaging effects of confusing the intellectual with the moral, of assuming that a literate person is necessarily a virtuous one, as does "The Vice of Reading" (Hochman 130). The difference is that Bunner Sisters examines the danger of indiscriminate reading to readers themselves, whereas "The Vice of Reading" presents the danger to literature.

Wharton's representation of reading habits and rhetorical practices in the novella reflects the cultural and educational ideology that the Bunner sisters have under the influence of patriarchy.

\section{Educational Ideology from Bunner Sisters' Reading Habits}

“That 'diffusion of knowledge' commonly classed with steam-heat and universal suffrage in the category of modern improvements," Wharton wrote in her 1903 essay "The Vice of Reading" published in The North American Review, "has incidentally brought about the production of a new vice - the vice of reading" (513). Hochman sees this essay as "a kind of companion piece" to Bunner Sisters (130). As Hochman states, through its image of lower-class reading habits Bunner Sisters draws attention to what Wharton saw as dangerously misplaced ideas about literacy and literary value (128).

The impoverished Bunner sisters have placed an illustrated copy of Longfellow's poems - a school prize of their father's - on a small table in the back room of their shop. Indeed, when he pays regular visits to the two women, Ramy entertains them by reading aloud Longfellow's poem "Maidenhood", one of the poet's most sentimental but least effective verses. The poem begins with the following stanzas:

Maiden! with the meek, brown eyes,

In whose orbs a shadow lies

Like the dusk in evening skies!

Thou whose locks outshine the sun

Golden tresses, wreathed in one,

As the braided streamlets run!

Standing, with reluctant feet,

Where the brook and river meet,

Womanhood and childhood fleet!

Gazing, with a timid glance,

On the brooklet's swift advance,

On the river's broad expanse!

Deep and still, that gliding stream,

Beautiful to thee must seem,

As the river of a dream.

Then why pause with indecision,

When bright angels in thy vision

Beckon thee to fields Elysian?

(Longfellow 39-40)

Longfellow seems to mark the highest point of culture and gentility in the world of the Bunner sisters, for whom Ramy's way of reading aloud poetry of Longfellow holds obvious and considerable appeal. They believe "his culture [soars] beyond the newspapers" and he is a suitable husband: "It was a very beautiful evening, and Ann Eliza thought afterward how different life might have been with a companion who read poetry like Mr. Ramy" (Wharton 49). The entire performance falsely implies that marriage to a man who can declaim Longfellow will be a genteel and cultured sequence of emotionally satisfying parlor activities. Charmed by this sentimental poem praising female innocence, the Bunner sisters believe Mr. Ramy to be the epitome of romance. By 
the end of the novella, however, Mr. Ramy proves to be anything but Prince Charming: an opium addict, a thief, and an abusive husband to Evelina Bunner. Returning to New York seriously ill and emotionally devastated, Evelina confides to her sister:

"At first I thought he was sick - I used to try to keep him home and nurse him. Then I saw it was something different. He used to go off for hours at a time, and when he came back his eyes kinder had a fog over them. Sometimes he didn't har'ly know me, and when he did he seemed to hate me. Once he hit me here." She touched her breast. (Wharton 96)

Although the middle-aged Bunner sisters bear little resemblance to the beautiful young lady eulogized in Longfellow's verse, their emotions are clearly stirred by the recitation of "Maidenhood", and romantic visions of Mr. Ramy ultimately cloud their better judgment. Ironically, Ramy's reading of Longfellow helps propel Evelina not only into the arms of a German immigrant, but also into greater poverty, Catholicism, and death (Hochman 133). Longfellow's poem is thus not only inappropriate for the aging spinsters; it is downright harmful (Koprince 24).

Many details of the story suggest that the sisters are sadly mistaken in their choice of texts from which to take their cues for living. As Ramy begins reading "Maidenhood" ("Maiden! With the meek, brown eyes") Evelina "lower[s] her lids" in sympathy or identification with the opening image (Wharton 49); that image, however, is absurdly at odds with the experiential reality of either sister. Ramy's reading only fosters delusion and facilitates exploitation.

Ann Eliza is a novel-reader, but novels have done her no good. Just as Evelina sees a reflection of herself in "Maidenhood", Ann Eliza takes pride in not having "fallen below her own ideals" at the "crucial moment of her life" when Mr. Ramy proposes to her (Wharton 59). After explaining to Ramy that she cannot marry him and recommending the attractions of Evelina, Ann Eliza, "uncertain how to end the conversation. at length [finds] courage to say (in the words of a novel she had once read): 'I don't want this should make any difference between us" (Wharton 58). According to Hochman, fiction here is "the model for life - a script to be followed, but the script bears little relation to reality": it is neither possible nor desirable that Ramy's proposal not "make any difference" in his relations with Ann Eliza (133). Ann Eliza's ideals, partly derived from fiction, have been far worse than useless.

\section{Ideology of Culture and Literacy in Rhetorical Practices}

Evelina has had some basic education. A combination of influences, both at home and at school, have endowed her with confused but inordinate respect for the literary expression of others; beyond that she has learned to imitate rhetorical models in her own letters (a conventional form deemed appropriate to women) (Hochman 138). Evelina's penmanship and prose well illustrate her ideology of culture and literacy.

Evelina's letters to Ann Eliza are written in a "pinched Spencerian hand" (Wharton 73), the type of handwriting, with its decorative flourishes, that was associated with a "feminine aesthetic" and was widely perceived by the writ- ing public in Victorian America as "a system of moral and spiritual uplift" (Thornton 50).

Ann Eliza and Evelina Bunner both admire the oratorical and impersonal tone of writing. Evelina's letters to Ann Eliza are eloquently written at the expense of effective communication. Eager to know the well-being of her younger sister, Ann Eliza reads the letters again and again, only to be left confused:

Ann Eliza had always secretly admired the oratorical and impersonal tone of Evelina's letters; but the few she had previously read, having been addressed to schoolmates or distant relatives, had appeared in the light of literary compositions rather than as records of personal experience. Now she could not but wish that Evelina had laid aside her swelling periods for a style more suited to the chronicling of homely incidents. She read the letter again and again, seeking for a clue to what her sister was really doing and thinking; but after each reading she emerged impressed but unenlightened from the labyrinth of Evelina's eloquence. (Wharton 74)

As is pointed out by Hochman, Wharton sets up a sharp contrast here, not just between "literary compositions" and accounts of "personal experience" but between "eloquence" and communication ("what her sister was really doing and thinking") (138). "During the early winter [Ann Eliza] received two or three more letters of the same kind, each enclosing in its loose husk of rhetoric a smaller kernel of fact" (Wharton 74).

\section{THE "VIRTUE" OF SELF-ABNEGATION}

Ann Eliza naively believes that right conduct will be rewarded by the Almighty God, as does her self-sacrifice to her sister. As the elder of the two, Ann Eliza provides shelter to and indulges her sister as much as possible: she always gives the first cup of tea and the largest slice of pie to Evelina, and carries out all the more boring and confining work. "She poured out Evelina's tea, adding some condensed milk from the jug, and cutting for her the largest slice of pie; then she drew up her own chair to the table." (Wharton 18). In Evelina's mind, her elder sister also has the responsibility to protest against her poor and drudging life. "Ann Eliza, in those days, had never dreamed of allowing herself the luxury of self-pity: it seemed as much a personal right of Evelina's as her elaborately crinkled hair." (Wharton 26). Ann Eliza's indulgence to and years of self-effacement in favor of her younger sister seem to be a denial of herself and prove to be inutile. Ironically, she gradually discovers that the one she has cared for with all her love is shallow, self-important and vain. To make it worse, Ann Eliza's self-sacrifice of her own happiness in exchange of her sister's leads to the tragedy and death of Evelina.

Ramy's untidy physical appearance, tawdry shop, and poor living arrangements all signal to the reader that Ramy is no Mr. Right, but both sisters are inordinately impressed with him; his apparent loneliness, his professional expertise (he sells and fixes clocks), and what the sisters see as his worldly sophistication all add to his attractions. When Ramy proposes marriage, Ann Eliza rejects the offer, sacrificing her own happiness (as she believes) for that of her 
sister. She plots for Evelina's happiness, stepping into the background whenever Ramy comes to call. Sending off the man she loves to court her sister, Ann Eliza has in fact traded her happiness for her sister's: "The elder sister's affection had so passionately projected itself into her junior's fate that at such moments she seemed to be living two lives, her own and Evelina's" (Wharton 63). However, it is what Ann Eliza deems appropriate and virtuous - self-sacrifice - that finally purchases death, rather than life, for her sister.

Ann Eliza assumes that her self-abnegation and "renunciation would guarantee romantic bliss and domestic contentment for Evelina; instead it has brought her misery, starvation, illness, and death" (Saunders 243). The perceptions Ann Eliza gains dramatically turn upside down when she finds out that Ramy is a drug addict, that he is discharged from job after job and that he loses all his money and Evelina's, and when Evelina comes back being seriously ill and dies tragically in the end. The elder sister faces a grave moral uncertainty, for her notions about right conduct have proved as unreliable as her judgments about character:

For the first time in her life she dimly faced the awful problem of the inutility of self-sacrifice. Hitherto she had never thought of questioning the inherited principles which had guided her life. Self-effacement for the good of others had always seemed to her both natural and necessary; but then she had taken it for granted that it implied the securing of that good. Now she perceived that to refuse the gifts of life does not ensure their transmission to those for whom they have been surrendered; and her familiar heaven was unpeopled. (Wharton 100)

Edith Wharton, through the self-recognition of Ann Eliza, shows that reliance on the traditionally female principle of renunciation and self-sacrifice is dangerous, and at the same time, she poses the question about the morality of self-abnegation. Ann Eliza's obvious selflessness finds itself to be bound up with a fatal egotism, and events rebuke her god-like attempt to assume responsibility for the happiness of another human being. Hence self-sacrifice may be the ultimate presumption, but Ann Eliza fails miserably at living second-hand through her sister; and the final bitter irony of her story is that she might just as well have lived for herself.

\section{OBEDIENCE TO AND DEPENDENCE ON THE AUTHORITY AS FALSE FEMALE IMAGES}

A good representation of Bunner sisters' obedience to and reliance on the authority is the false female images they have, which reinforce women's subservient roles and perpetuate their lower status. Ann Eliza and Evelina Bunner conform to the destructive roles and accept carefully controlled definitions of themselves, unable or unwilling to resist the messages perpetuated by the Church and the patriarchal society. Because resistance to such messages is rather difficult, patriarchy prevents female individuals from achieving their "innately ordained Self-direction toward Happiness" (Daly 2).

\section{Obedience to the Male God Reflecting the Passive Victims}

Both Ann Eliza and Evelina Bunner have religious belief. They both believe in Christianity and trust in the goodness of God at the very beginning of the story, but Evelina is converted to Roman Catholicism after severe emotional traumas including the premature death of her child.

Daly critiques religious symbols as one institutionalized source of the false female images, arguing that institutionalized religion, particularly Catholicism and Christianity, offers women a "derivative status" in relation to men and perpetuates a "planetary caste system" with women always at the bottom (Daly 328-30). Roman Catholicism is a denomination, and is, therefore, a subset of Christianity. In principle, Christianity is built solely on the Holy Scriptures, the written Word of God. The Bible is the only infallible rule of faith, being sufficient to give people the sure knowledge of the Gospel for their salvation and holiness. Christian doctrines advocate that Jesus came down from Heaven to save mankind that commit the "original sin" inherited from Adam. Humans cannot save themselves or ascend on their own to a higher level; only God - the male God - is good, and therefore only God is able to save a person. Only by obeying to what God decrees can humans attain salvation from sin. As regards women, obedience to men is thus their salvation. Roman Catholicism demands submission of the intellect and will to the doctrines taught by the Roman magisterium (the Pope and bishops). These two religions advocate either obedience or submission despite the subtle differences. The result is the dehumanization of women in the eyes of many and an "alienated self", an "authentic being [who] struggles to say its own name" (Daly 328). Institutionalized religion causes women to internalize the identity and roles imposed upon them "so that what may seem to be an experienced identity is in reality a false identity" (Daly 328).

The Bunner sisters place "a Bible and prayer-book" (Wharton 20). The image "Bible" has repeatedly appeared in the story, which signifies their absolute trust in the Almighty. According to the Christian doctrines, humans are supposed to be obedient and submissive to God, and only when they obey God's message can they live a happy life. Likewise, women must be submissive to men so that they can redeem themselves and achieve happiness. The conversation between Ann Eliza and Evelina at the end of the story is a typical example of the former's Christian piety:

"Well, I've been through worse than that. I've been to hell and back."

“Oh, Evelina - don't say it, sister!” Ann Eliza implored, shrinking from the unholy word. She knelt down and began to rub her sister's feet beneath the bedclothes. (Wharton 95)

Ann Eliza is afraid to say the unholy word "hell" which is forbidden by God. As she is a pious follower of the Christian faith, she is supposed to be submissive and obedient to God. Having suffered the severe traumas, Ann Eliza finally begins to experience an epiphany - a growing feminist consciousness - as she feels that "she could no longer trust in the 
goodness of God, and there was only a black abyss above the roof of Bunner Sisters" (Wharton 100).

\section{Dependence on Men as False Path to Happiness and Self-worth}

The small basement shop that the Bunner sisters run is located "in a side-street already doomed to decline" (Wharton 13), a wasteland of urban squalor, with "lids of tomato-cans, old shoes, cigar-stumps and banana skins, cemented together by a layer of mud, or veiled in a powdering of dust ..." (Wharton 14). Despite the unfavorable or even appalling conditions, they manage to run their business independently. Before Ann Eliza buys the clock on the occasion of Evelina's birthday they go to the Square every morning to see what time it is, which might be seen as a sign of independence.

The Bunner sisters' possession of the clock, however, saves them the trouble of going to the Square, and since then they are fettered by the patriarchal society as Ramy enters their life. The depiction of the clock is always in association with the description of Ramy, signifying the two sisters' growing dependence on him about almost everything: "... and the sisters fell into the habit of saying to each other, in moments of uncertainty: 'We'll ask Mr. Ramy when he comes,'..." (Wharton 40). And whatever Ramy's verdict is, they accept it with "fatalistic readiness" (Wharton 40). At the same time, Ramy seems to be an indispensable part of their lives when he visits them with increasing frequency: "...Mr. Ramy, who had by this time become as much a part of their lives as the letter-carrier or the milkman..." (Wharton 41). They are also inclined to consult Ramy about how to use their own savings:

...the sisters had decided to advise with Mr. Ramy; and on Ann Eliza, as the head of the house, this duty had devolved. Mr. Ramy, when consulted, had not only confirmed the dress-maker's report, but had offered to find some safe investment which should give the sisters a higher rate of interest than the suspected savings bank... (Wharton 46)

Another detail also demonstrates Ann Eliza's complete dependence on men. When a long period of time elapses without hearing a word about Evelina, Ann Eliza longs to turn to someone for advice. The person she turns to is still a man, Mr. Hawkins, because, from her point of view, a man is capable enough of seeking information that women cannot: "Then she remembered Mrs. Hawkins, or rather her husband, who, though Ann Eliza had always thought him a dull uneducated man, was probably gifted with the mysterious masculine faculty of finding out people's addresses." (Wharton 77).

In addition, Ann Eliza and Evelina Bunner see marriage to a man as a vehicle to happiness and a measure of self-worth. Ann Eliza goes into a state of "dreamy ecstasy" (Wharton 59) as if she is "floating on a summer sea" (Wharton 56) when she receives Ramy's proposal of marriage. Being chosen by Ramy causes Ann Eliza to feel that her value has increased, which is judged according to Ramy's criteria. As to Evelina, she thinks that her marriage with Ramy will pull her out of the dull life that she has lived for many years, but in fact, she falls into the trap that Ramy sets and finally loses her life.

The details presented above illustrate how the Bunner sisters have changed from their full independence in the initial stage to excessive dependence on men since their first encounter with Mr. Ramy.

\section{CONCLUSION}

The female ideology of Bunner sisters, which is constructed under the influence of patriarchal world, is examined through the angle of misplaced conception of culture and literacy, the "virtue" of self-abnegation and absolute obedience to and dependence on the authority, which are the key elements that make the sisters the passive victims of the male dominated world.

In the meantime, Bunner Sisters probes common assumptions about how women should be educated and expected to live. The miserable life of the two sisters demonstrates their false conceptions of education and literacy, i.e. they mistakenly take a literate man as a moral one. In addition, the novella criticizes the elder sister Ann Eliza's so-called "virtue" of self-sacrifice profoundly influenced by the conventional wisdom, and the two sisters' total obedience to and dependence on the authority.

A major factor that affects the Bunner sisters is the dominance pervasive in the patriarchal society in which they adopt their ideologies. The word "ideology" usually designates a way of thinking which is systematically mistaken, a false consciousness. If, however, we believe in the power of representation to construct reality, the distinction between truth and falsehood becomes hard to maintain. After going through a life of misfortune and adversity, Ann Eliza begins to develop a feminist consciousness. The novella Bunner Sisters carries the possible implications that women should begin to reject the deception of patriarchy and define their own lives, defying the "deception of patriarchal history" and discovering a world in which women identify the sources of deception in all of their complex and simple forms and create new identities, new Selves, and new frameworks for living (Daly 33).

\section{REFERENCES}

Daly, M. (1972). "The Women's Movement: An Exodus Community." Religious Education 67:328-30.

Daly, M. (1978). Gyn/Ecology: The Metaethics of Radical Feminism. Boston: Beacon Press.

Daly, M. (1984). Pure Lust: Elemental Feminist Philosophy. Boston: Beacon Press.

Flower, D. (2007). “Another Wharton.” The Hudson Review 60,3: 501-08.

Hochman, B. (2006). "The Good, the Bad, and the Literary: Edith Wharton's Bunner Sisters and the Social Contexts of Reading." Studies in American Naturalism 1, 1\&2: $128-43$.

Koprince, S. (1999). "Wharton and Longfellow." American Literary Realism 31: 21-30. 
Longfellow, H. W. (1894). "Maidenhood." Poems of Henry Wadsworth Longfellow, 39-40. Boston: Houghton Mifflin.

Saunders, J. P. (1997). "Ironic Reversal in Edith Wharton's Bunner Sisters." Studies in Short Fiction 14: 241-45.

Starhawk, D. (1987). Truth or Dare: Encounters with Power, Authority, and Mystery. San Francisco: Harper \& Row.
Starhawk, D. (1988). Dreaming the Dark: Magic, Sex and Politics. Boston: Beacon Press.

Thornton, T. P. (1996). Handwriting in America: A Cultural History. New Haven: Yale University Press.

Wharton, E. (1903)."The Vice of Reading." The North American Review 177: 513-21.

Wharton, (1916). Bunner Sisters. London: Electric Book Company. 